\title{
The Rule of Law, Fair Trial and Human Dignity: The Protection of EU Values After LM
}

\author{
Catherine Dupré
}

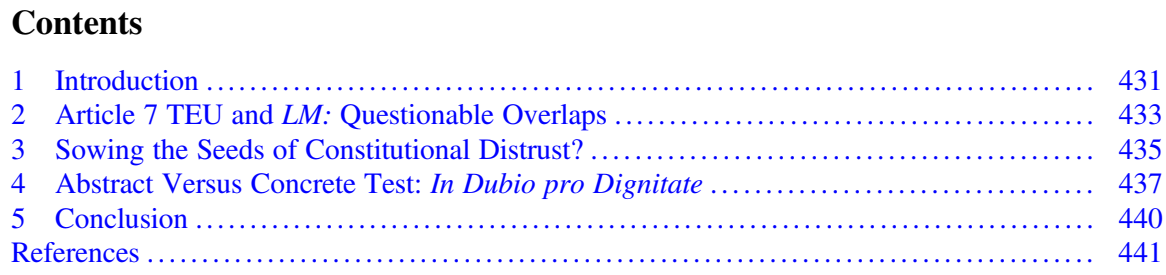

\begin{abstract}
The 2018 CJEU ruling in $L M$ highlighted the importance of judicial independence for the rule of law and protection of the right to fair trial. In so doing, the judgment raised problematic questions about the relationship between Article 2 values and the EU Charter rights, and their connection with mutual trust. This chapter considers these issues through the lens of human dignity, which is both the first foundational value under Article 2 and the first right in the EU Charter. By discussing how the $L M$ judgment raises the constitutional status of the right to a fair trial, this chapter argues that a focus on human dignity could effectively link Article 2 values with EU Charter rights and facilitate assessment of their respective breach.
\end{abstract}

\section{Introduction}

The design faults of Article 7 TEU proceedings and the delayed responses of EU institutions to the rapid deterioration of democratic standards in Hungary and Poland have triggered renewed interest in the mainstream EU judicial procedures as possible

This is a reworked version of 'Individuals and Judges in Defense of the Rule of Law', Verfassungsblog (28 July 2018).

C. Dupré $(\square)$

University of Exeter, Exeter, UK

e-mail: c.c.l.dupre@exeter.ac.uk 
channels to address some of these concerns. The European Court of Justice (CJEU) Grand Chamber judgment of 25 July 2018 in $L M^{1}$ was promptly dissected by commentators across Europe. ${ }^{2}$ In many ways, this case illustrates EU constitutionalism at its best: despite not being obliged to do so, the Irish judge made a request under Article 267 TFEU, bringing together concerns raised by the pending Article 7 TEU procedure against Poland and the more technical and narrow issue of fair trial under Article $47 \mathrm{EU}$ Charter. The CJEU addressed these following the urgent procedure. Seizing the first opportunity to intervene on an issue directly relevant to the ongoing Article 7 TEU procedure against Poland, ${ }^{3}$ the CJEU stayed on the path opened by Aranyosi ${ }^{4}$ as a way of seeking to address the problematic issue of judicial independence at the core both of the preliminary ruling reference and of the Article 7 TEU procedure against Poland.

At first glance, in $L M$ the CJEU appeared to make decisive strides with regard to the rule of law, stepping up as a prominent participant in the discussion triggered by reforms to the judiciary in Poland and Hungary. Notably the CJEU did not wait for Article 7 TEU proceedings to come to an end ${ }^{5}$ in order to devise its own tests and assessment mechanisms, inviting Member States' courts to apply them. The $L M$ case can certainly therefore be understood as promoting the role of Member States' courts in assessing what are generally referred to as the rule of law crises and related attacks on judicial independence in fellow Member States. The message of the CJEU is clear. When there is a 'real risk of systemic or generalised deficiencies' affecting the principle of judicial independence constructed by the Court as the 'essence' of the right to a fair trial under Article $47 \mathrm{EU}$ Charter, the presumption of mutual trust that underpins the European Arrest Warrant (EAW) system can be rebutted by the executing authorities (i.e. the domestic courts) unless they are satisfied that the essence of the applicant's right under Article 47 will be protected in the issuing Member State. In carrying out the $L M$ abstract test, the Irish High Court predictably found that there was a 'real risk connected with a lack of independence of the courts in Poland on account of systemic or generalised deficiencies' ${ }^{6}$ Predictably too, the Irish High Court did not find that in the concrete situation faced by the applicant upon his being surrendered to Poland he would be exposed to a breach of his right to a fair trial under Article 47.2 EU Charter and to a flagrant denial of justice. ${ }^{7}$ This anti-climactic outcome of the Irish High Court judgment brings into sharp relief

${ }^{1}$ CJEU, Case C-216/18 PPU, Minister for Justice and Equality, ECLI:EU:C:2018:586.

${ }^{2}$ von Bogdandy et al. (2018) and Peers (2018).

${ }^{3}$ Kochenov et al. (2017).

${ }^{4}$ CJEU, Cases C-404/15 and C-659/15 PPU Aranyosi and Caldararu, ECLI:EU:C:2016:198.

${ }^{5}$ At the time of delivery only a reasoned proposal had been issued by the EU Commission in December 2017.

${ }^{6}$ Irish High Court, Minister for Justice and Equality v. Artur Celmer (No. 5) [2018] IEHC 639, para. 93.

${ }^{7}$ Irish High Court, Minister for Justice and Equality v. Artur Celmer (No. 5) [2018] IEHC 639, paras. 105 and 117. 
some of the shortcomings of the CJEU's judgment in $L M$ and points to the ruling's potentially wider significance in relation to safeguarding the EU foundational values under Article 2 TEU.

\section{Article 7 TEU and $L M$ : Questionable Overlaps}

In its $L M$ judgment the CJEU managed to connect Article 7 TEU and preliminary proceedings while keeping the two avenues on parallel tracks (paragraphs 70-72). First, the CJEU noted the 'particular relevance' of a reasoned proposal of the Commission against Poland adopted under Article 7(1) TEU (paragraph 61). The reasoned proposal is one of the materials that have to be 'objective, reliable, specific and properly updated concerning the operation of the system of justice in the issuing Member State' that may be considered in this process by the executing authority (paragraph 61). On its own, however, it is not sufficient to establish the 'real risk' and the executing court is required to make a wider investigation, with the assessment having to be carried out on the basis of the right to a fair trial (Article $47 \mathrm{EU}$ Charter), and not of the EU value under Article 2 (paragraph 62). The second element shared by the Article 7 TEU procedure and the $L M$ tests is the principle of judicial independence, a phrase not used by the Irish High Court in its preliminary reference, which focussed on the fundamental right to a fair trial and on a 'real risk of flagrant denial of justice' (paragraph 25). The two are easily related, but the CJEU's switch to judicial independence is arguably strategic as it makes it possible to establish a hermeneutic continuum between Article 2 TEU, which mentions the rule of law, and Art. $47 \mathrm{EU}$ Charter, which protects the right to a fair trial:

In that regard, it must be pointed out that the requirement of judicial independence forms part of the essence of the fundamental right to a fair trial, a right which is of cardinal importance as a guarantee that all the rights which individuals derive from EU law will be protected and that the values common to the Member States set out in Article 2 TEU, in particular the value of the rule of law, will be safeguarded. (paragraph 48)

In the above, the CJEU noted that the right to a fair trial under Article $47 \mathrm{EU}$ Charter is included under the scope of Article 2 TEU, referred to in Council Framework Decision 2002/584/JHA of 13 June 2002, about which the Irish High Court sought clarification. In so doing the CJEU justified its entry into the territory of Article 2 TEU, from which it is excluded by Article 7 TEU, which promotes an exclusively political approach to breaches of Article 2 TEU values. The CJEU language however keeps clear boundaries between the two territories: rule of law issues fall under Article 7 TEU, and fair trial can-and should-be addressed by courts. Having established the principle of judicial independence as a bridge between the two, the CJEU provided guidance to domestic courts for determining the quality of judicial independence. In this respect, the CJEU arguably came very close to encouraging domestic courts to substitute Article 7 TEU, with the two procedures being at the very least mutually complementary. The reasoned proposal 
produced under Article 7.1 TEU will certainly be useful for domestic courts' determination of a 'real risk of systemic or generalised deficiencies'. Repeated positive findings by domestic courts against Poland under the second test of $L M$ could potentially provide further evidence to feed into the Article 7 TEU procedure, thus possibly encouraging speedier action through this channel.

If it is certainly well-intentioned, i.e. encouraging action in a situation of a real risk of deficiencies in judicial independence, this promotion of judicial involvement in Articles 2 and 7 TEU territory is not unproblematic. Firstly, the complex pluralism in relation to judicial independence across the $\mathrm{EU}$ has been highlighted as rendering any assessment of its 'systemic' quality in a given Member State (abstract test) an arduous task to say the least. ${ }^{8}$ As will be recalled from the early stages of pre-Article 7 proceedings, identifying and gathering appropriate documentation on the quality of the rule of law in Poland and Hungary have not been easy tasks, and that is for institutions that are much better equipped than any domestic court being invited to perform that test. Therefore, in this respect $L M$ does not provide much clarification, as the reasoned proposal is considered as just one of the possible materials at the disposal of domestic courts. In addition, the abstract test arguably creates a wide power gap between a single court (and a single judge in many cases) and the issuing Member State, subject to the early stage of Article 7 TEU proceedings. Secondly, the executing Member State court's task of checking the quality of judicial independence in the issuing Member State with regards to the pending EAW before them (concrete test) amounts to what was evocatively compared to 'herculean hurdles'. In particular, while the CJEU in $L M$ appeared keen to promote a 'dialogue between the executing judicial authority and issuing judicial authority' (paragraph 77), scepticism has been expressed about this, with scholars noting that such a dialogue might not go so smoothly in practice. ${ }^{10}$ If a court-to-court exchange of information can be workable, the Irish High Court's effort to engage in this arguably confirmed the difficulty in obtaining unequivocal answers from the issuing authorities in a situation of real risk of systemic or generalised deficiencies. ${ }^{11}$ Thirdly, domestic courts having to determine single-handedly the quality of judicial independence and of the right to a fair trial in the issuing Member State is likely going to delay the procedure of EAW and generate extra costs, which would somehow have to be absorbed by the executing judicial authority. Paradoxically, this might trigger a knock-on effect for fair trial in the executing Member State, depending on the volume of EAW with Poland (or Hungary) going through its court system. In this situation, one possible silver lining might come from recent CJEU case law according to which the host state has to cover the cost for granting asylum seekers

\footnotetext{
${ }^{8} \operatorname{Kosar}$ (2016).

${ }^{9}$ Bard and Ballegooij (2018), pp. 8-9.

${ }^{10}$ Bracken (2018) and Biernat (2018).

${ }^{11}$ Irish High Court, Minister for Justice and Equality v. Artur Celmer (No. 5) [2018] IEHC 639, paras. 85-91.
} 
'the minimum conditions for reception' pending their application. ${ }^{12}$ In relation to the EAW, the extra cost for the executing Member State might, so it could be hoped, alert the Member States' authorities to the seriousness of the situation and encourage them to be more pro-active at the EU level, including through Article 7 TEU. Fourthly and finally, in its endeavour to bring Article 47 EU Charter closer to Article 2 TEU, the CJEU forgot to draw on Article 6 European Convention on Human Rights (ECHR). This apparent forgetfulness is odd considering the EU Charter's requirements under Article 52 paragraph 3 and Article 53 that the CJEU refer to ECHR case law when there is a correspondence between the EU Charter and ECHR rights. It becomes odder considering that the Irish High Court had phrased its Article 267 TFEU question with explicit reference to the 'flagrant denial of justice' test developed by the European Court of Human Rights under Article 6 ECHR (paragraph 25). As a result of this omission, the CJEU's focus on the 'essence of the right to a fair trial' arguably made a complicated situation even more complicated, leading to the Member State's court having to work out the questionable distinctions between the CJEU and the ECHR thresholds for an acceptable quality of fair trial.

\section{Sowing the Seeds of Constitutional Distrust?}

In $L M$ the CJEU widened the possibility of rebutting the mutual trust presumption, while emphasising its 'fundamental importance' (paragraph 36) and defining it as the 'cornerstone' of judicial cooperation in criminal matters (paragraph 41). The CJEU had recognised this possibility in previous case law, ${ }^{13}$ however, in $L M$ it did so for the first time in relation to a non-absolute right, namely the right to a fair trial. The CJEU was cautious to ring-fence this exceptional approach by requiring that both steps of the Aranyosi test be taken in this context too. The pending Article 7 TEU proceeding against Poland was no doubt one of the reasons for extending the Aranyosi and NS tests involving absolute rights (human dignity, and the prohibition of torture, inhuman or degrading treatment). Nevertheless, as mentioned above, on its own, the existence of a reasoned proposal under Article 7 is not a sufficient criterion for finding a clear risk of systemic or generalised deficiencies, it only forms part of the material that the executing authority can consider in its assessment. This arguably makes mutual distrust a possibility for other situations of systemic deficiencies affecting other non-absolute EU Charter rights. This is all the more possible as mutual trust is a core principle in numerous other EU procedures, ${ }^{14}$ therefore likely to concern a range of fundamental rights. In addition, the mutual trust standard

\footnotetext{
${ }^{12} \mathrm{CJEU}$, Case C-179/11 Cimade and GISTI v Ministre de l'Intérieur, de l'Outre-Mer, des Collectivités Territoriales et de l'Immigration, ECLI:EU:C:2012:594.

${ }^{13}$ CJEU, Case C-411/10 N.S. and Others, ECLI:EU:C:2011:865 and CJEU, Cases C-404/15 and C-659/15 PPU Aranyosi and Caldararu, supra note 4. Korenica and Coli (2016), p. 542.

${ }^{14}$ Frackowiak-Adamska (2018).
} 
in $L M$ (i.e. a real risk of systemic or generalised deficiencies in the protection of Article 47 paragraph 2) appears to be lower than under the EAW Framework Decision 2002/584 which stays within the Article 7 TEU perimeter, requiring a 'serious and persistent breach' of one of the foundational values under Article 2 TEU (paragraph 10).

This has further ramifications as mutual trust (and mutual recognition which derives from it) lies at the core of the whole EU constitutional framework and is anchored in the principle of sincere cooperation of Article 4 paragraph 3 TEU. This therefore arguably raises the question whether $L M$ is planting the seeds of constitutional distrust, fighting fire with fire, and undermining ultimately the constitutional principle of mutual trust, without which the EU cannot operate effectively. The CJEU seems to be well aware of this risk, as evidenced by its focus on an essentialist definition of the right to a fair trial, and its connection to Article 2 TEU values. Even so, the scope for mutual distrust remains wide as non-absolute rights represent the vast majority of the EU Charter rights, and Article 2 TEU foundational values are numerous, creating the possibility for an even greater number of combinations between the two. Moreover, this risk of encouraging mutual distrust has to be seen in the current political context of a series of unprecedented crises, which have in common a radical questioning of, and distrust in, the EU's ability to fulfil its own mission and/or to fulfil a mission that Member States would like it to fulfil. In addition, and in relation to the rule of law crises, pre-Article 7 proceedings and Article 7 have created a general climate of deep distrust between the EU on the one hand, and Poland ${ }^{15}$ and Hungary ${ }^{16}$ on the other. This sentiment flourishes on a widespread resentment and sense of deep social injustice among Central Europeans many of whom feel they have been treated as second class citizens by the EU since joining it. Finally, it must be borne in mind that the CJEU itself might not be viewed by Poland nor Hungary with the greatest level of trust. The few rulings it delivered on the issue of judicial independence had little effect on remedying the problem, especially in the early stages of the Hungarian situation, ${ }^{17}$ but they were given great publicity as the first unequivocal condemnation of the judicial reforms by an EU institution. Concerns about the possible germination of this seed of constitutional distrust are therefore not unrealistic, especially as the tension between the EU and Central and Eastern European Member States increases. ${ }^{18}$ As the rebuttability of

\footnotetext{
${ }^{15}$ ‘Poland Cries Foul as EU Triggers 'Nuclear Option' over Judicial Independence', The Guardian 20 December 2017: https://www.theguardian.com/world/2017/dec/20/eu-process-poland-votingrights.

${ }^{16}$ Interview with Hungarian Foreign Affairs Minister, Péter Szijjarto, with Le Monde: 'La procédure de sanction est une revanche contre la Hongrie', 14 December 2018.

${ }^{17}$ E.g. CJEU, Case C-286/12 Commission v. Hungary, ECLI:EU:C:2012:687.

${ }^{18}$ See e.g. European Parliament Resolution of 12 September 2018 calling for Art. 7 proceeding, P8-TA-PROV (2018) 0340; CJEU, Case C-619/18 European Commission v Poland, ECLI:EU: C:2018:910. The EU's relationships with Romania are also marked by a 'climate of defiance': 'La Roumanie en pleine dérive illibérale: Bucarest assure au 1 Janvier sa première présidence de l'UE, dans un climat de défiance inédit avec Bruxelles', Le Monde, 1-2 January 2019.
} 
mutual distrust ultimately rests on the right to a fair trial, the constitutional status of this right therefore requires closer attention.

\section{Abstract Versus Concrete Test: In Dubio pro Dignitate}

It is suggested here that one way of resolving the mutual trust conundrum is to seek to ensure that its rebuttal promote a constitutional good of higher importance or status than mutual trust. This is perhaps what the CJEU has sought to achieve, albeit incompletely, in its $L M$ judgment by emphasising the definition of the right to a fair trial as the essence of judicial independence and its connection to Article 2 TEU. Therefore an alternative, or perhaps complementary, approach might arguably be to take the lesson of NS and Aranyosi a step further. This could involve joining the dots between the right to a fair trial and human dignity which is codified both under Article 1 EU Charter ${ }^{19}$ and Article 2 TEU. This would give the right to a fair trial an elevated constitutional status, i.e. close if not identical to that of 'inviolable human dignity'. As such it would arguably be robust enough to provide a suitable ground for rebutting the presumption of mutual trust, considered both in its specific (e.g. EAW) embodiment and in its constitutional dimension under Article 4 paragraph 3 TEU. This would therefore legitimise constitutional distrust in situations of systemic or generalised deficiencies.

This suggestion needs unpacking. Firstly, this follows NS and Aranyosi in which the mutual trust presumption gave way to the protection of human dignity in the form of the prohibition of torture and inhuman and degrading treatment, considered under Article 1 and Article 4 EU Charter (NS), and under Article 4 EU Charter (Aranyosi). This makes both practical and theoretical sense. Practically, the treatments involved under Article 4 EU Charter are the most violent and brutal ones falling short of killing a human being; and this therefore arguably legitimises an executing judicial authority's decision to suspend the surrendering of a person to another Member State if that person faces a real risk of being subjected to Article 4 EU Charter types of treatment. Theoretically, the Article 4 EU Charter absolute prohibition is the strongest prohibition of the EU human rights system, and this status is further strengthened by Article 15 ECHR according to which Article 3 ECHR (Article 4 EU Charter counterpart) may never be curtailed even in emergency situations. As a result, it is argued that there may not, and should not, be any mutual trust towards Member States where people face a real risk of being tortured or subjected to inhuman and degrading treatment or punishment, due to systemic or generalised deficiencies. Finally and importantly, breaches of Article 4 EU Charter do not only result in violations of this person's human dignity under the EU Charter, they also attack human dignity as the first foundational value of the EU under Article 2 TEU and the principle of inviolability of human dignity codified under Article 1 EU Charter. As

${ }^{19}$ Dupré (2014), pp. 3-24. 
such, the commitment to human dignity holds together the EU's first foundational value under Article 2 TEU and the most important fundamental right of the EU Charter (from which all the other rights flow), therefore bringing together the realms of values and rights. It is suggested that the presumption of mutual trust can therefore be rebutted not only because of the real risk of treatments contrary to Article $4 \mathrm{EU}$ Charter in situations of systemic and generalised deficiencies, but also because the considered Member State might be breaking the EU foundational promise never again to destroy humanity as codified both under Article 2 TEU and the EU Charter. ${ }^{20}$

The connection between the commitment to protect human dignity and the right to a fair trial is not made explicit in $L M$, but it arguably lies very close to the surface of the judgment. Drawing it out would therefore strengthen the legitimacy of extending the rebuttability of the mutual trust presumption in the specific case of the non-absolute right to a fair trial. Many, if not all, non-absolute EU Charter rights can be related in one way or another to human dignity which is, as the 2017 Report on the Application of the EU Charter reminds us, 'the basis of all fundamental rights' and 'part of the essence of all other rights' ${ }^{21}$ It has to be noted, however, that the right to a fair trial stands out as a sine qua non condition for the respect of human dignity, as only if it exists can human dignity (and rights) victims be heard, effectively seek justice and ultimately start healing the violation. Moreover, it is argued that the right to a fair trial plays a crucial (if not exclusive) role in making it possible for a democracy to learn from its mistakes, and to seek to prevent further breaches of human dignity and of human rights from occurring again. Above all, grounding the rebuttability of the mutual trust presumption in human dignity considered in its inviolable (Article $1 \mathrm{EU}$ Charter) and foundational (Article $2 \mathrm{TEU}$ ) natures has another benefit, as this explicitly limits the situations in which the presumption can be rebutted, therefore addressing the concern of constitutional distrust discussed above. Namely, it might be rebutted only when the four rights codified under the dignity title of the EU Charter face a real risk of being breached. This, it is suggested, limits the problematically wide scope of pluralist definitions and practices of judicial independence, which could easily lead to double standards in addition to problems of identification in a given situation of alleged breach of this principle. Moreover and crucially, this draws attention to other situations in which

\footnotetext{
${ }^{20}$ Dupré (2015), pp. 66-74.

${ }^{21}$ 'Human dignity, as protected under Art. 1 of the Charter, is the basis of all fundamental rights. It guarantees the protection of human beings from being treated as mere objects by the state or by their fellow citizens. It is a right, but also part of the essence of all other rights. Therefore it must be respected when any other rights are restricted. All subsequent rights and freedoms on dignity, such as the right to life and the prohibition of torture and slavery, add specific protection against violations of dignity. They must be equally upheld in order to protect other rights and freedoms in the Charter, for example the freedom of expression and the freedom of association. None of the rights laid down in the Charter may be used to harm the dignity of another person.' 2017 Report on the Application of the EU Charter of Fundamental Rights, SWD (2018) 304 final, p. 12. Emphasis added.
} 
the presumption of mutual trust may be legitimately rebutted, such as those of servitude, slavery, forced labour and human trafficking which are absolutely banned under Article $5 \mathrm{EU}$ Charter (the last right of the dignity title).

As a result, the $L M$ judgment can be read in two ways. One, as the judgment through which the CJEU opened the gates to mutual distrust in instances of a real risk of breach of (potentially all) non-absolute EU Charter rights. Alternatively, LM can be read as elevating the constitutional status of the right to a fair trial to a level close (if not totally similar) to the absolute protection of human dignity. In this reading, it is suggested that the CJEU builds on the EU commitment to making human dignity inviolable by securing the strongest possible constitutional basis for a key procedural mechanism required for its effective protection. Exploring this interpretation might give the CJEU the opportunity to shed light on what is at stake with a breach of Article 2 TEU values, which arguably goes far beyond the significance of the rule of law and judicial independence, to include the constitutional ontology and raison d'être of a democratic European Union anchored in the dignity promise.

Finally, drawing out the connection between the foundational commitment to protect human dignity and the right to a fair trial makes it possible to address the shortcomings of the $L M$ two-stage test. This can arguably be achieved, by reverting to the approach put forward in $N S .{ }^{22}$ Namely, the presumption that in situations of systemic deficiencies in conditions of reception for asylum seekers $(N S)$, and, by extension, of judicial independence $(L M)$ in fellow Member States, issuing Member States 'cannot be unaware' of the risk of breaches to Article 4 TEU (NS) and by extension to Article 47 TEU ( $L M)$. This double negative presumption has three main advantages over the two-stage test advocated in $L M$. First, by rendering the $L M$ two-stage test unnecessary, it prevents the constitutionally awkward positioning of the executing Member State courts (a single judge in most cases), both vis-à-vis the issuing Member State and vis-à-vis Article 7 TEU (abstract test). In an Article 7 TEU context, the existence of a reasoned proposal would be sufficient for confirming the double negative presumption, while keeping Member State courts outside the boundaries of Article 7 TEU. Second, adopting the NS approach would contribute to addressing the nonsensical second and concrete stage of the $L M$ test, whereby the executing Member State court is expected to trust the information provided by the issuing Member State court, about which it has just established that the mutual trust presumption may not apply. Third, considering the foundational nature of human dignity (Article 2 TEU) and its paradigmatic function in shaping human rights in the EU (Article 1 EU Charter), it would be wise not to dilute human dignity in chance concretisations depending in part on the judges' subjectivity, but to retain it as a whole in its abstraction and as the foundational promise on which the EU project rests.

${ }^{22}$ CJEU, Case C-411/10 NS and Others, ECLI:EU:C:2011:865, para. 91. 


\section{Conclusion}

Disappointing for some, exciting for others, the ultimate significance of the $L M$ judgment might not mainly lie in its connections with Article $7 \mathrm{TEU}$, and in its ability to offer new tools or new channels for Member States' courts to address the systemic deterioration of the rule of law in fellow Member States. Rather, this judgment's principal merit might prove to be the connections it established between the set of foundational values under Article $2 \mathrm{TEU}$ and rights contained in the EU Charter, therefore bringing the Charter and its rights to the political core of the EU.

At least two questions remain at this stage. One is whether the hermeneutic route taken by $L M$ from Article $2 \mathrm{EU}$ to EU Charter rights can be reversed, namely whether the judicial finding of systemic and generalised deficiencies of the NS and Aranyosi type in relation to the right to a fair trial, and in relation to one or all of the dignity rights under Title $1 \mathrm{EU}$ Charter might be one of the factors for triggering pre-Article 7 or Article 7 proceedings. The other question is about which institution is best placed to safeguard the foundations of a constitutional order such as the EU. In the framework of European constitutionalism developed on the basis of a collaboration between the EU, the Council of Europe and their common Member States, safeguarding the foundational values in any of these orders has not been left to that order alone. Rather, protection of their foundational values has been entrusted to a dynamic equilibrium of sovereignty. ${ }^{23}$ In this respect, the EU still has a way to go. As $L M$ shows, despite its visible endeavour to draw red lines, the judicial collaboration between the CJEU and Member States' courts at the heart of the preliminary reference process cannot effectively address the shortcomings of Article 7 TEU mechanisms for the protection of the EU foundational values. Even in the event of a negative finding by the issuing court, implementing $L M$ does not contribute to advancing Article 7 TEU. If anything, the Irish High Court ruling arguably weakens Article 7 TEU by demonstrating that when there is a proven 'real risk of systemic or generalised deficiencies' in relation to the right to a fair trial, it can still be appropriate to surrender applicants in individual instances. An appropriate custodian for the EU foundational values, together with procedural avenues to access it effectively by those who need it most, remain therefore to be imagined and designed.

Failing an institutional reform, hermeneutic connections with the ECHR case law is a necessary and simple step for the CJEU to take towards protecting its foundational values and safeguarding democracy in the EU. The ECHR is not just a convenient—and illusory - safety net for the protection of fair trial when the EU mechanisms fail, as pointed out by the Irish High Court. ${ }^{24}$ As will be recalled, the ECHR case law is a valuable source of inspiration for interpreting EU Charter rights and ensuring that standards of protection are consistent across the EU and the Council of Europe. Arguably, it is also a keystone for European constitutionalism,

\footnotetext{
${ }^{23}$ Dupré (2015), p. 5.

${ }^{24}$ Irish High Court, Minister for Justice and Equality v. Artur Celmer (No. 5) [2018] IEHC 639, para. 124 .
} 
which brings together the constitutional orders and the EU and its Member States through their respective commitment to it. ${ }^{25}$ Ultimately, the ECtHR provides the overarching narrative as to why it is important to protect these rights and these values in a democratic society. By omitting to refer to ECHR case law under Article 6 ECHR, the CJEU might have missed a golden opportunity to take part in this powerful narrative and to give meaning to the EU democratic project at a time where it faces its greatest challenges.

Acknowledgments I am grateful to Gabor Halmai and Stephen Skinner for their comments on earlier versions of this chapter.

\section{References}

Bard P, Ballegooij W (2018) Judicial independence as a precondition for mutual trust? The CJEU in Minister for Justice and equality v LM. New J Crim Law:1-13

Biernat S (2018) How to Assess the Independence of Member State Courts? Verfassungsblog, 28 July 2018. https://verfassungsblog.de/how-to-assess-the-independence-of-member-statecourts/

Bracken C (2018) Episode 5 of the Celmer Saga - The Irish High Court Holds Back. Verfassungsblog, 28 November 2018. https://verfassungsblog.de/episode-5-of-the-celmersaga-the-irish-high-court-holds-back/

Dupré C (2014) Article 1: human dignity. In: Peers S, Hervey T, Kenner J, Ward A (eds) The EU Charter of fundamental rights: a commentary. CH Beck/Hart/Nomos, Oxford, pp 3-24

Dupré C (2015) The age of dignity: human rights and constitutionalism in Europe. Bloomsbury/ Hart, Oxford

Frackowiak-Adamska A (2018) Drawing Red Lines with No (Significant) Bite - Why an Individual Test is not Appropriate in the LM Case. Verfassungsblog 30 July 2018. https://verfassungsblog. de/drawing-red-lines-with-no-significant-bite-why-an-individual-test-is-not-appropriate-in-thelm-case/

Kochenov D, Pech L, Scheppele KL (2017) The EU Commission's Activation of Art. 7: better late than never?, EU Law Analysis, 23 December 2017. http://eulawanalysis.blogspot.com/2017/12/ the-european-commissions-activation-of.html

Korenica F, Coli D (2016) No more unconditional 'mutual trust' between the Member States: an analysis of the landmark decision of CJEU in Aranyosi and Caldararu. Eur Human Rights Law Rev 21:542

Kosar D (2016) Perils of judicial self-government in transitional societies: holding the least accountable branch to account. Cambridge University Press, Cambridge

Peers S (2018) Mutual trust and independence of the judiciary after the CJEU judgment in LM - a new era or business as usual?, EU Law Anal 15 August 2018. http://eulawanalysis.blogspot. com/2018/08/mutual-trust-and-independence-of.html

von Bogdandy A, Bogdanowicz P, Canor I, Schmidt M, Taborowski M (2018) Drawing Red Lines and Giving (some) Bite - the CJEU's Deficiencies Judgment on the European Rule of Law. Verfassungsblog, 3 August 2018. https://verfassungsblog.de/drawing-red-lines-and-givingsome-bite-the-cjeus-deficiencies-judgment-on-the-european-rule-of-law/

\footnotetext{
${ }^{25}$ Dupré (2015), pp. 179-183.
} 
Catherine Dupré is an Associate Professor of Comparative Constitutional Law at the University of Exeter, UK.

Open Access This chapter is licensed under the terms of the Creative Commons Attribution 4.0 International License (http://creativecommons.org/licenses/by/4.0/), which permits use, sharing, adaptation, distribution and reproduction in any medium or format, as long as you give appropriate credit to the original author(s) and the source, provide a link to the Creative Commons license and indicate if changes were made.

The images or other third party material in this chapter are included in the chapter's Creative Commons license, unless indicated otherwise in a credit line to the material. If material is not included in the chapter's Creative Commons license and your intended use is not permitted by statutory regulation or exceeds the permitted use, you will need to obtain permission directly from the copyright holder. 